Figure 2

RE-ENGINEERED HOUSE BUYING AND SELLING PROCESSES

New
Processes

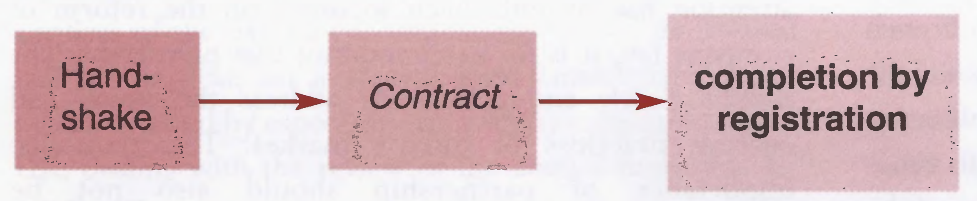

Present

Processes

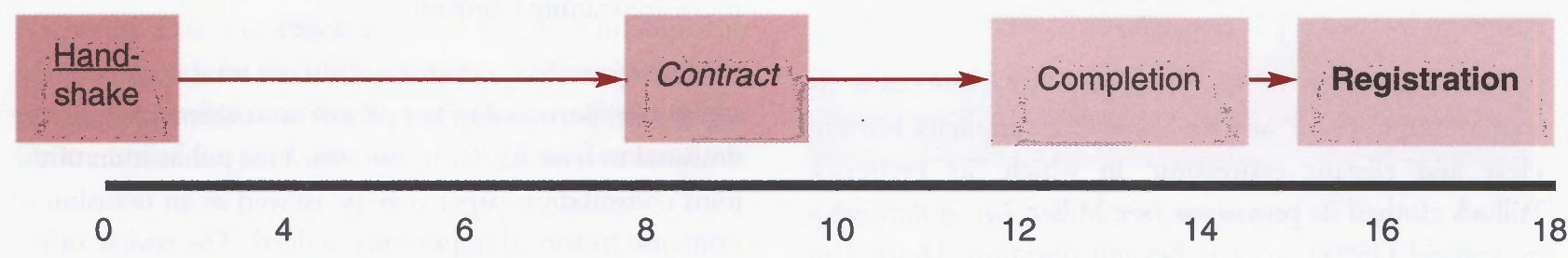

weeks

\title{
Partnership law for the new millennium
}

\author{
by Professor Johan Henning
}

This article is taken from the introduction given by Professor Henning at the conference on partnership law reform staged on 4 June by the Centre for Corporate Law and Practice at the IALS, the Law Commission for England and Wales, and the Scottish Law Commission.

$\mathrm{P}$ artnership is of great antiquity. Some of its primitive non-commercial forms have obvious origins in family arrangements and clan activities of the most ancient and elementary kind. As a profit-seeking and sharing device it must be as old as co-operative economic endeavour, starting with the first feeble stirrings of a rudimentary capitalistic system. Its use in various guises and forms was recorded long before the time of the Romans, pointing to the very remote origins of some of its underlying concepts. Thus, for instance, an essential element of modern partnership, the sharing of profits, appears in the agricultural portion of the Code of Hammurabi, compiled circa 1700 BC. Historically its course can be traced from the ancient Near Eastern civilisations to classical Greece and Rome and hence onward through medieval commercial practices and usury-evading devices, the Italian trading communities and far-reaching enterprises of the Renaissance to its present day position as one of the three most important forms of enterprise in the business world. Indeed some of the basic principles of partnership as a business organisation seem to have changed astonishingly little in a period spanning more than four thousand years.

Whatever the respective merits of the numerous and conflicting theories on the origin and development of various partnership concepts may be, it seems sufficient to note that the Roman societas, the medieval commenda and the lex mercatoria left their imprint on the several types of partnership of modern law. The massive contribution of Roman partnership law can hardly be underestimated. Its contribution is especially marked, both in so far as the basic concept of partnership as a consensual contract of the utmost good faith as well as the relationship constituted by it between the partners inter se are concerned.

Developments occasioned by the lex mercatoria include the acceptance of the doctrines of mutual agency and solitary liability for partnership obligations. Equally 
important is the recognition in most civil law jurisdictions of the so-called mercantile (entity) theory, viewing the partnership as a persona separate and distinct from the partners composing it.

The medieval commenda-concept of limiting the liability of non-managing investors spread from Italy into French commercial law, emerging as the société en commandite, the predecessor of the present day limited or commanditarian partnership. From France it was incorporated into other legal systems on the Continent Due to the doctrine of the undisclosed principal, in common law jurisdictions the concept had to be introduced by legislation (in the United Kingdom by the Limited Partnership Act 1907).

The importance of the Partnership Act 1890 with its 'rather limpid prose' and the 'deceptive simplicity, born of clear and elegant expression' in which Sir Frederick Pollock clothed its provisions (see Miller, Law of Partnership in Scotland (1994), p.5) is beyond question. Drafted in 1879 , it was brought into the House of Commons 1880, modified in 1882, 1883, 1884 and 1889 and finally enacted in 1890 (by which time it had undergone substantial amendment), this seminal piece of Victorian legislation was intended as partial codification of the considerable number of common law and equitable principles developed by the courts. It has served as a meticulous example for most Commonwealth jurisdictions and has strongly influenced the American Uniform Partnership Act 1914. Its provisions are to be found in more than 30 other partnership Acts and ordinances with dates of inception ranging from 1891 to 1980 .

The Partnership Act now shows the signs of its rather advanced age, especially when compared with the innovative revisions in the United States which resulted in the National Conference of Commissioners on Uniform State Laws recommending Revised Uniform Partnership Acts for enactment ranging from 1992 to 1997 . Not only does the Partnership Act, for instance, still refer to the Companies Act 1862 as the present main companies legislation in force and also still enshrines very much outdated doctrine, but it is rightly perceived as failing to keep up with the reasonable expectations of those running and dealing with the more than 680,000 business partnerships in the country, which is almost as many as there are trading companies in the United Kingdom, with a combined annual turnover of $£ 151,523$ million and at least 2.77 million employees in 1997.

Hopefully, this is all destined to change. Following on the Law Commission's recommendation to this effect in November 1994, on 20 November 1997 the DTI requested the Law Commission and Scottish Law Commission to undertake jointly a review of partnership law. On 13 September 2000 both Law Commissions released a comprehensive joint consultation paper envisaging a 'thorough shake-up' of the law of partnership, leaving the Limited Partnership Act 1907 for later analysis.
The news release is headed 'Partnership law for the new millennium', showing the intention not only of comprehensive modernisation but also that this initiative should dovetail with the DTI's company law review programme. Both Commissions emphasised that while attention has recently been focussed on the reform of company law, it is no less important that partnership law should clearly and sufficiently address the needs and current practices of today's market. The economic importance of partnership should also not be underestimated - as has been noted above, there are almost as many partnerships in the United Kingdom as there are trading companies.

After more than a century of almost total neglect by the legislature, partnership law proper is, it seems, at long last destined to have its day in the sun. This publication of the joint consultation paper may be viewed as an occasion of immense historical importance indeed. The review of the law of partnership which can remotely compared to the present consultation paper as far as in-depth of research, fundamental reconsideration of basis principles and wide ranging recommendations are concerned, is the Report on Partnership Law by the chancery barrister $\mathrm{H}$ Bellenden Ker, prepared on instruction of the Board of Trade in 1837. Although this report referred particularly to the expedience of introducing the concept of the commanditarian or limited partnership on the French or, for that matter, the Continental model, the report was shelved. In the event a limited liability for partners did form the subject of a Bill securing its second reading in 1854: it was incorrectly viewed as the object of the introduction of the 'Act to Amend the Law of Partnership', also known as 'Bovill's Act' in 1865, and was finally introduced only in 1907. My fervent prayer is that the same will not befall the present meritorious initiative, for which both Commissions are to be highly recommended.

The Commissions address and suggest proposals for reform to the three main problems with existing partnership law, namely the firm as an entity, unnecessary closure of business and mechanisms for dissolution of solvent partnerships. Justice cannot fully be done in this brief introduction to the great deal of careful thought and deliberation devoted to them. This consultation paper should be compulsory reading for every business and company lawyer. For partnership lawyers in particular it represents not only the opportunity of a lifetime, but conceivably also the best one of the next millennium!

It remains to be emphasised that this initiative is not to be viewed in isolation. The Commissions themselves refer to the comprehensive review of company law presently under way under the auspices of the DTI. It is patently obvious that a seamless match between the two initiatives has much to recommend it. A consultation document recommending the removal of the 20-partner limit has been released by the DTI on 4 April 2001. A similar 
recommendation is to be found in the joint consultation document.

It gives me great pleasure to announce that it is envisaged that a follow-up conference will be arranged by the Centre for Corporate Law and Practice under the auspices of the two Law Commissions during the second half of the year, on a second joint consultation paper eagerly awaited by especially every venture capitalist in the UK, dealing with the review of the Limited Partnership Act 1907. There are also a number of 'firsts' for this conference, which I am glad to be allowed to mention. This is the first conference arranged by the Centre for Corporate Law and practice under my directorship, the first conference by the Centre dealing exclusively with the law of partnership, and the first conference offered by the Centre under the joint auspices of both Law Commissions (as far as I know, it is also the first conference in which Law Commissioners from both countries are participating).

Last but not least, this is the first conference in the United Kingdom on the joint consultation paper and, I am sure, the fist conference on partnership law in the United Kingdom ever to be so well attended. The IALS is very grateful to the two Law Commissions, and Judge Diana Faber, for their support and encouragement.

\section{Professor Johan Henning}

Director, Centre for Corporate Law and Practice, Institute of Advanced Legal Studies; Dean, Faculty of Law, University of the Free State, Blocmfontein

\title{
The impact of the Human
} Rights Act 1998 on evidence and disclosure in judicial review proceedings

\author{
by Jonathan Bracken
}

\section{INTRODUCTION}

As public awareness of the Human Rights Act 1998 (HRA) develops it is likely to have a significant impact on the volume and nature of judicial review proceedings. The new grounds provided by the HRA for challenging the actions of public authorities will inevitably lead to changes in the way the Administrative Court deals with such cases. As the Bowman Report (Review of the Crown Office List, chaired by Sir Jeffery Bowman, March 2000), noted:

... under the Human Rights Act, the courts will have to spend more time establishing questions of fact in addition to questions of law. For example, in deciding whether interference with a right can be justified, they may need to give stricter scrutiny to the factual basis of the decision or consider the wider social context. In the past, very little time has been taken on factual matters and discovery and cross examinations have been rare.' (Chap. 5, para. 8 )
The most noticeable changes in judicial review proceedings are likely to be in relation to:

- the evidence considered by the court, and

- the growing need for the court to order disclosure.

As the Bowman Report states, 'further evidence may be necessary under the Human Rights Act.'(Chap. 5, para. 70), and 'orders for discovery [as it was then known] may well be required more frequently in the future, particularly in relation to Human Rights Act cases.' (Chap. 5, para. 69)

Neither the Civil Procedure Rules nor the HRA provide detailed guidance on how judicial review proceedings need to be adapted to cope with this change. The European Convention on Human Rights is equally silent on the issue - evidence and disclosure merely being a facet of the Article 6 right to a fair trial - and the jurisprudence 